\title{
JIMMBA
}

\section{Pengaruh Self-Efficacy, Kompensasi Finansial, dan Kepuasan Kerja Terhadap Komitmen Organisasi}

Tika Ragil Saputri' ${ }^{1}$, Marynta Putri Pratama ${ }^{2}$

1,2Sekolah Tinggi Ilmu Ekonomi Putra Bangsa

Email: ragils886@gmail.com¹, maryntaputri@yahoo.com²

\section{ARTICLE INFO}

Article History:

Received: July $7^{\text {th }} 2020$

Accepted: October $16^{\text {th }} 2020$

Published: October 21 2020

Keywords: Self-Efficacy,

Kompensasi Finansial,

Kepuasan Kerja dan

Komitmen Organiasasi.

\begin{abstract}
Penelitian ini bertujuan untuk menguji dan menganalisis pengaruh self-efficacy, kompensasi finansial dan kepuasan kerja terhadap komitmen organiasasi. Populasi dalam penelitian ini berjumlah 99 orang. Sampel dalam penelitian ini menggunakan metode sampel jenuh. Penelitian ini menggunakan pendekatan kuantitatif, data untuk penelitian ini diperoleh melalui angket yang telah diisi oleh responden yang sudah ditentukan. Metode analisis data yang digunakan adalah metode analisis regresi berganda. Hasil penelitian menunjukan bahwa self-efficacy berpengaruh positif dan signifikan terhadap komitmen organisasi. Kompensasi finansial berpengeruh signifikan terhadap komitmen organisasi. Kepuasan kerja berpengaruh positif dan signifikan terhadap komitmen organiasasi. Secara simultan self-efficacy, kompensasi finansial dan kepuasan kerja berpengaruh positif dan signifikan terhadap komitmen organiasasi.
\end{abstract}

\section{Pendahuluan}

Sumber daya manusia adalah suatu aspek yang sangat penting dalam berjalannya suatu perusahaan untuk mencapai visi, misi, dan tujuan organisasi. Keberhasilan perusahaan tergantung pada organisasi yang ada pada perusahaan. Mengingat peran yang cukup penting tersebut, maka segala upaya akan dilakukan untuk mengatur kinerja manusia agar lebih efektif dan efisien dalam organisasi. Oleh karena itu agar sebuah organisasi atau perusahaan dapat lebih berkembang secara optimal, maka rekruitmen terhadap orang-orang potensial berkomitmen tinggi untuk mengembangkan sumber daya manusia menjadi pilihan strategis yang harus dilakukan pengelola organisasi. Mempertahankansumber daya manusia di perusahaan bukan hal yang mudah, banyak perusahaan memberikan penawaran lebih baik untuk calon karyawan. Karyawan akan lebih tertarik untuk berkerja di tempat lain apabila di tempat kerja yang sekarang tidak dapat memenuhi kebutuhannya. Hal ini menjadi tugas penting bagi perusahaan agar karyawan menajadi loyal terhadap perusahaan dan enggan meninggalkan pekerjaannya.

PT. Cita Yasa Perdana Surabaya yaitu perusahaan kontraktor yang bergerak dibidang jasa, yaitu jasa pencatatan meter dan pelayanan teknik. Lokasi PT. Cita Yasa Perdana Surabaya beralamat di Jl. Gayung Kebonsari Rt 11 Rw 01, Surabaya, Jawa Timur. PT. Cita Yasa Perdana 
Surabaya merupakan vendor dari PT. PLN (Persero) ULP Kebumen yang memenangkan tender jasa outsorcing pada pekerjaan pembaca meter untuk di pekerjakan menjadi petugas billman.

Billing Management (Billman) merupakan pekerjaan yang bekerja dalam mengelola pembacaan dan pencatatan angka $\mathrm{kWh}$ meter, pengendalian piutang yang bersifat edukasi serta melaksanakan pemutusan sementara dan Penataan Data Pelanggan dan Jaringan (PDPJ/ DIL). Pada PT. Cita Yasa Perdana Surabaya memiliki petugas billman berjumlah 99 orang. Dimana mencangkup di 23 wilayah diantaranya Kebumen, Pejagoan, Sruweng, Karanganyar, Adimulyo, Puring, Petanahan, Buluspesantren, Klirong, Ambal, Mirit, Bonorowo, Prembun, Kutowinangun, Poncowarno, Alian, Karangsambung, Sadang, Karanggayam, Padureso, Wadaslintang, Kaliwiro, dan Kalibawang. Peran mereka penting untuk memberikan pelayanan yang maksimal. Apabila komitmen organisasi tingkat turnover meningkat, maka organisasi akan kehilangan sumber daya manusia. Oleh karena itu, suatu perusahaan sangatlah penting dalam menjaga karyawan untuk tetap loyal terhadap perusahaan.

Diketahui tingkat komitmen organisasi pada petugas billman PT. Cita Yasa Perdana Surabaya baik. Salah satu cara untuk menilai tingkat komitmen organisasi karyawan adalah dengan cara melihat tingkat turnover karyawan dalam perusahaan.

Tabel 1. Data Turnover Petugas Billman di PT. Cita Yasa Perdana Surabaya

\begin{tabular}{llllll}
\hline Tahun & $\begin{array}{l}\text { Jumlah } \\
\text { Petugas } \\
\text { Awal } \\
\text { Tahun }\end{array}$ & $\begin{array}{l}\text { Jumlah } \\
\text { Petugas } \\
\text { Akhir } \\
\text { Tahun }\end{array}$ & $\begin{array}{l}\text { Petugas } \\
\text { Masuk }\end{array}$ & $\begin{array}{l}\text { Petugas } \\
\text { Keluar }\end{array}$ & $\begin{array}{l}\text { Turnover } \\
\text { (\%) }\end{array}$ \\
\hline 2019 & 99 & 99 & 1 & 1 & $1 \%$ \\
2018 & 98 & 99 & 9 & 8 & $8 \%$ \\
2017 & 99 & 98 & 2 & 3 & $3 \%$ \\
\hline
\end{tabular}

Sumber: PT. Citayasa Perdana Surabaya, 2019

Berdasarkan Tabel 1 tingkat turnover pada petugas billman PT. Cita Yasa Perdana Surabaya tergolong rendah. Dimana diketahui pada tahun 2017 tingakat turnover karyawan mencapai 3\% yaitu, adanya petugas billman yang pensiun. Pada tahun 2018 turnover menigkat 5\% menjadi $8 \%$ dikarenakan, ada 1 orang petugas billman meninggal dan 2 orang petugas billman pensiun, 2 orang petugas billman SP3, dan 3 orang petugas billman resign. Sedangkan, di tahun 2019 tingkat turnover menjadi 1\% dikarenakan 1 orang petugas billman meninggal. Menurut (Gillis, 1994) turnover karyawan dikatakan normal berkisar antara 5\%-10\% dan dikatakan tinggi apabila diatas $10 \%$.

Berdasarkan wawancara dengan petugas billman, adanya kemauan dari petugas billman untuk tetap setia berada di organisasi tersebut. Karena, adanya rasa nyaman dengan hubungan kerja, petugas billman juga dapat komunikasi baik dengan Supervisor, Koordinator dan rekan kerja. Selanjutnya, ada rasa saling membantu demi terwujudnya tujuan organisasi.

Robbins dan Judge (2008:74) menyatakan bahwa komitmen organisasi (Organizational Commitment) merupakan keadaan dimana karyawan berpihak pada organisasi tertentu dan tujuannya, serta keinginannya untuk mempertahakan keanggotaannya dalam organisasi. Luthans (2002:259) juga menyatakan bahwa komitmen organisasi merupakan suatu sikap mengenai kesetiaan karyawan terhadap organisasi tempat mereka bekerja. Banyak hal yang mempengaruhi komitmen organsasi diantaranya self-efficacy, kompensasi finansial dan kepuasan kerja. 
Self-efficacy merupakan keyakinan individu mengenai sejauh mana seseorang mampu mengerjakan tugas yang diberikan dan mencapai tujuan, merencanakan tindakan untuk mencapai hasil yang diharapkan. Berdasarkan wawancara dengan petugas billman diketahui saat penjadwalan catat meter mereka menemukan kesulitan untuk mendapatkan nomor meteran dilapangan seperti, rumah pelanggan yang dipagar dan terkunci, tetapi petugas billman mampu mengatasinya dengan memfoto keadaan tersebut diaplikasi ACMT(Apikasi Catat Meter Terpusat). Ketika penjadwalan penarikan piutang saat rumah pelanggan di kunjungi tidak ada, petugas billman tekun untuk mengunjunginya kembali. Dan ketika pelanggan tidak mau membayar, petugas billman akan mengedukasinya supaya pelanggan mengerti dan mau membayar tepat waktu. Maka, peran self-efficacy sangat penting karena dapat meningkatakan komitmen dalam organisasi.

Menurut Garcia (2015), self-efficacy mengacu pada keyakinan individu tentang kemampuannya untuk menyelesaikan tugasnya dengan berhasil. Hal ini terbukti penting karena mempengaruhi ketekunan dan upaya seseorang dalam mencapai kesuksesan dalam hidupnya. Self-efficacy dapat menentukan bagaimana seseorang merasakan, berpikir, memotivasi diri sendiri dan berkelakuan.

Selanjutnya, kompensasi finansial merupakan pendapatan yang berupa uang, barang langsung atau tidak langsung yang diterima karyawan sebagai imbalan atau balas jasa yang diberikan kepada perusahaan. Dimana menurut wawancara dengan petugas billman, gaji yang diberikan sesuai dengan beban kerja yang diberikan dari perusahaan, mendapatkan Asuransi seperti, BPJS Kesehatan, BPJS Tenaga Kerja, dan DPLK(Dana Pensiun Lembaga Keuangan). Petugas billman juga mendapatkan fasilitas smartphone dari perusahaan untuk mempermudah pekerjaan saat catat meter di aplikasi ACMT(Aplikasi Catat Meter Terpusat). Apabila ada yang mampu mencapai target yang diberikan akan mendapatkan reward dari perusahaan berupa uang.

Simamora (2006) terkait dengan gaji yang diterima oleh karyawan tersebut. Hal ini penting karena dapat menjadi usaha dari perusahaan untuk mempertahankan karyawan dan mengurangi tingkat turnover pada petugas billman.

Berdasarkan wawancara dengan petugas billman, selama bekerja di PT. Cita Yasa Perdana Surabaya mereka merasa puas dengan pekerjaan itu sendiri, jika target yang diberikan perusahaan tercapai akan diberikan imbalan berupa uang, akrab dengan semua baik dengan Supervisor, Koordinator dan rekan kerja. Apabila ada yang belum mencapai target akan di beri motivasi dari Koordinatornya agar mencapai target. Penilaian dirasa adil oleh petugas billman.

Menurut Robbins (2003:78) kepuasan kerja adalah sikap umum terhadap pekerjaan seseorang yang menunjukan perbedaan antara jumlah penghargaan yang diterima pekerja dan jumlah mereka yakni seharusnya mereka terima. Sedangkan Handoko (2010:193) menyatakan bahwa kepuasan kerja (job satisfaction) adalah keadaan emosional yang menyenangkan atau tidak menyenangkan bagaimana para karyawan memandang pekerjaan mereka. Kepuasan kerja mencerminkan perasaan seseorang terhadap pekerjaannya.

\section{Kajian Teori dan Telaah Literatur}

\section{Komitmen Organisasi}

Komitmen organisasi juga sering didefinisikan sebagai (1) keinginan kuat untuk tetap sebagai anggota organisasi tertentu, (2) keinginan untuk berusaha keras sesuai dengan kenginan 
organisasi, dan (3) keyakinan tertentu, dan penerimaan nilai dan tujuan organisasi. Dengan kata lain, komitmen organisasi merupakan sikap yang merefleksikan loyalitas karyawan pada organisasi dan keberhasilan serta kemajuan yang berkelanjutan (Fred Luthans, 2006:249). Menurut Buchanan (1974) ada 3 (tiga) batasan komitmen organisasi yaitu:
a. Identifikasi Organisasi
b. Keterlibatan Kerja
c. Loyalitas Organisasional

\section{Self-efficacy}

Bandura (2006:199) mendefinsikan self-efficacy sebagai rasa kepercayaan seseorang bahwa ia dapat menunjukan perilaku yang dituntut dalam suatu situasi yang spesifik. Menurut Brown dkk (Manara, 2008:36), indikator dari self-efficacy mengacu pada dimensi self-efficacy yaitu level, strength, dan generality. Dengan melihat ketiga dimensi ini, maka terdapat beberapa indikator dari self-efficacy yaitu:

a. Yakin dapat menyelesaikan tugas tertentu

b. Yakin dapat memotivasi diri untuk melakukan tindakan

c. Yakin bahwa diri mampu berusaha dengan keras gigih dan tekun

d. Yakin bahwa diri mampu bertahan menghadapi hambatan dan kesulitan

e. Yakin dapat meyelesaikan permasalahan diberbagai situasi

\section{Kompensasi Finansial}

Menurut Samsudin (2016:192) kompensasi finansial merupakan kompensasi dari perusahaan kepada karyawannya yang diwujudkan dalam bentuk uang. Menurut (Samsudin, 2016:193 dan Martocchio, 2016:247) pengukuran variabel kompensasi finansial dapat dilakukan melalui presepsi karyawan terhadap kompensasi finansial yang diterimanya dengan indikator:
a. Gaji
b. Reward
c. Tunjangan
d. Asuransi
Kepuasan Kerja

Handoko (2014:135) menyatakan bahwa kepuasan kerja (job satisfaction) merupakan keadaan emosional yang menyenangkan atau tidak menyenangkan bagi para karyawan dalam memandang pekerjaan mereka. Menurut Robbins dan Judge (2009:119), menyatakan ada 4 (empat) indikator kepuasan kerja yaitu:
a. Kepuasan terhadap pekerjaan
b. Kepuasan terhadap imbalan
c. Kepuasan terhadap supervisi kerja
d. Kepuasan terhadap rekan kerja

Model Empiris 


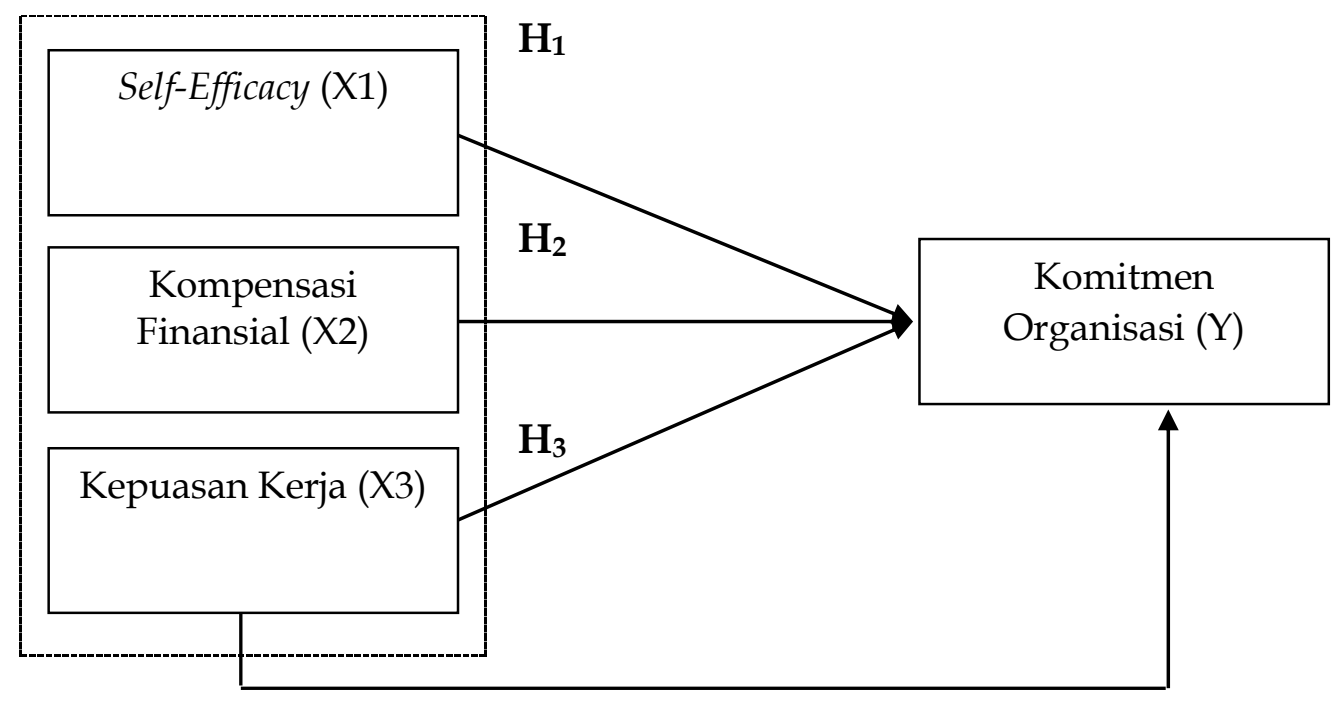

$\mathbf{H}_{4}$

\section{Gambar 1. Model Penelitian}

\section{Metode Penelitian}

Penelitian ini dilakukan di PT. Cita Yasa Perdana Surabaya. Alasan memilih PT. Cita Yasa Perdana Surabaya adalah karena menurut data, sebagaimana ditampilkan pada pendahuluan, perusahaan ini memiliki tingkat pergantian petugas billman yang rendah. Rendahnya turnover menunjukkan tingginya komitmen keorganisasian petugas billman pada perusahaan tersebut.

Teknik pengumpulan data dalam penelitian ini menggunakan cara (1) wawancara; (2)kuesioner dan (3) studi pustaka. Alat pengumpulan data dalam penelitian ini dilakukan dengan menggunakan kuesioner yang ditunjukan untuk memperoleh jawaban dari responden. Populasi dalam penelitian ini adalah petugas billman di PT.Cita Yasa Perdana Surabaya yang berjumlah 99 orang dan teknik pengambilan sampel yang digunakan adalah teknik nonprobability sampling dengan teknik sampling jenuh. Besarnya sampel dalam penelitian ini sebanyak 99 responden.

Teknik analisis yang digunakan ada dua cara yaitu analisis deskriptif dan analisis statistik. Analisis statistik yang digunakan meliputi: (1) Uji Validitas dan Uji Realiabilitas; (2) Uji Asumsi Klasik; (3) Analisis Regresi Linier Berganda dan (4) Uji Hipotesis. Alat bantu pengolahan data menggunakan SPSS for windows versi 23.0.

\section{Hasil dan Pembahasan}

\section{Uji Validitas}

Dengan level of significacnce 95\% maka dasar analisisnya (Ghozali, 2009):

a. Apabila rhitung $>$ rtabel $(\alpha=0,05)$ berarti item tersebut valid.

b. Apabila rhitung $<$ rtabel $(\alpha=0,05)$ berarti item tersebut tidak valid. 
Tabel 2. Hasil Uji Validitas Self-Efficacy

\begin{tabular}{cccc}
\hline Butir & Nilai $\mathbf{r}_{\text {hitung }}$ & Nilai $\mathbf{r}_{\text {tabel }}$ & Keterangan \\
\hline X1.1 & 0,715 & 0,1975 & Valid \\
X1.2 & 0,598 & 0,1975 & Valid \\
X1.3 & 0,574 & 0,1975 & Valid \\
X1.4 & 0,591 & 0,1975 & Valid \\
X1.5 & 0,724 & 0,1975 & Valid \\
\hline
\end{tabular}

Tabel 2. Hasil Uji Validitas Kompensasi Finansial

\begin{tabular}{cccc}
\hline Butir & Nilai $\mathbf{r}_{\text {hitung }}$ & Nilai $\mathbf{r}_{\text {tabel }}$ & Keterangan \\
\hline X2.1 & 0,799 & 0,1975 & Valid \\
X2.2 & 0,797 & 0,1975 & Valid \\
X2.3 & 0,753 & 0,1975 & Valid \\
X2.4 & 0,710 & 0,1975 & Valid \\
\hline
\end{tabular}

Tabel 3. Hasil Uji Validitas Kepuasan Kerja

\begin{tabular}{cccc}
\hline Butir & Nilai $\mathbf{r}_{\text {hitung }}$ & Nilai $\mathbf{r}_{\text {tabel }}$ & Keterangan \\
\hline X3.1 & 0,671 & 0,1975 & Valid \\
X3.2 & 0,800 & 0,1975 & Valid \\
X3.3 & 0,753 & 0,1975 & Valid \\
X3.4 & 0,751 & 0,1975 & Valid \\
\hline
\end{tabular}

Tabel 4. Hasil Uji Validitas Komitmen Organisasi

\begin{tabular}{cccc}
\hline Butir & Nilai $\mathbf{r}_{\text {hitung }}$ & Nilai $\mathbf{r}_{\text {tabel }}$ & Keterangan \\
\hline Y1 & 0,688 & 0,1975 & Valid \\
Y2 & 0,695 & 0,1975 & Valid \\
Y3 & 0,631 & 0,1975 & Valid \\
Y4 & 0,735 & 0,1975 & Valid \\
\hline
\end{tabular}

Berdasarkan tabel diatas maka dapat disimpulkan bahwa variabel self-efficacy, kompensasi finansial, kepuasan kerjadan komitmen organisasi valid, karena nilai $r_{\text {hitung }}>r_{\text {tabel }}$.

Uji Reabilitas

Suatu kuesioner dikatakan reliabel jika jawaban responden terhadap pernyataan atau pernyataan yang digunakan konsisten dengan melihat hasil koefisien cronbach alpha dan dipakai adalah 0,6 (Ghozali, 2009).

Tabel 5. Hasil Uji Realiabilitas

\begin{tabular}{clcc}
\hline No. & \multicolumn{1}{c}{ Variabel } & $\begin{array}{c}\text { Cronbach } \\
\text { Alpha }\end{array}$ & Keterangan \\
\hline 1. & Self-Efficacy & 0,645 & Reliabel \\
2. & Kompensasi & 0,761 & Reliabel \\
& Finansial & & \\
3. & Kepuasan Kerja & 0,704 & Reliabel \\
4. & Komitmen & 0,620 & Reliabel \\
& Organisasi & &
\end{tabular}

Berdasarkan Tabel 5 hasil analisis dapat dijelaskan bahwa seluruh variabel yang dipakai dalam penelitian ini dinyatakan reliabel karena nilai $\mathrm{r}$ alpha $>0,60$. 


\section{Uji Asumsi Klasik}

\section{Uji Multikolinieritas}

Tidak adanya multikolinieritas ditentukan dengan angka VIF dibawah 10 dan tolerance diatas 0,1 (Ghozali, 2009:95).

Tabel 6. Hasil Uji Multikolinieritas

\begin{tabular}{|c|c|c|c|c|c|}
\hline \multirow[b]{2}{*}{ Model } & \multicolumn{2}{|c|}{$\begin{array}{l}\text { Unstandardized } \\
\text { Coefficients }\end{array}$} & \multirow{2}{*}{$\begin{array}{c}\begin{array}{c}\text { Standardized } \\
\text { Coefficients }\end{array} \\
\text { Beta }\end{array}$} & \multicolumn{2}{|c|}{$\begin{array}{l}\text { Collinearity } \\
\text { Statistics }\end{array}$} \\
\hline & $\bar{B}$ & Std. Error & & Tolerance & VIF \\
\hline 1 (Constant) & 2,257 & 1,105 & & & \\
\hline $\mathrm{X} 1$ & 162 & ,065 & 195 & ,884 & 1,131 \\
\hline $\mathrm{X} 2$ & ,365 & ,078 & ,433 & 620 & 1,613 \\
\hline $\mathrm{X} 3$ & ,258 & ,098 & 246 & 612 & 1,634 \\
\hline
\end{tabular}

a. Dependent Variable: Komitmen Organisasi

Berdasarkan Tabel 6 dapat dijelaskan bahwa pada bagian collinearity statistic menunjukkan angka VIF tidak lebih besar dari 10 dan tolerance lebih dari 0,10. Berdasarkan hasil tersebut dapat diketahui bahwa model regresi ini tidak terdapat moltikolinearitas, sehingga model dapat dipakai.

\section{Uji Heteroskedastitas}

Uji heteroskedastitas bisa dilakukan dengan metode scaterplott heteroskedastitas (Ghozali, 2009:126).

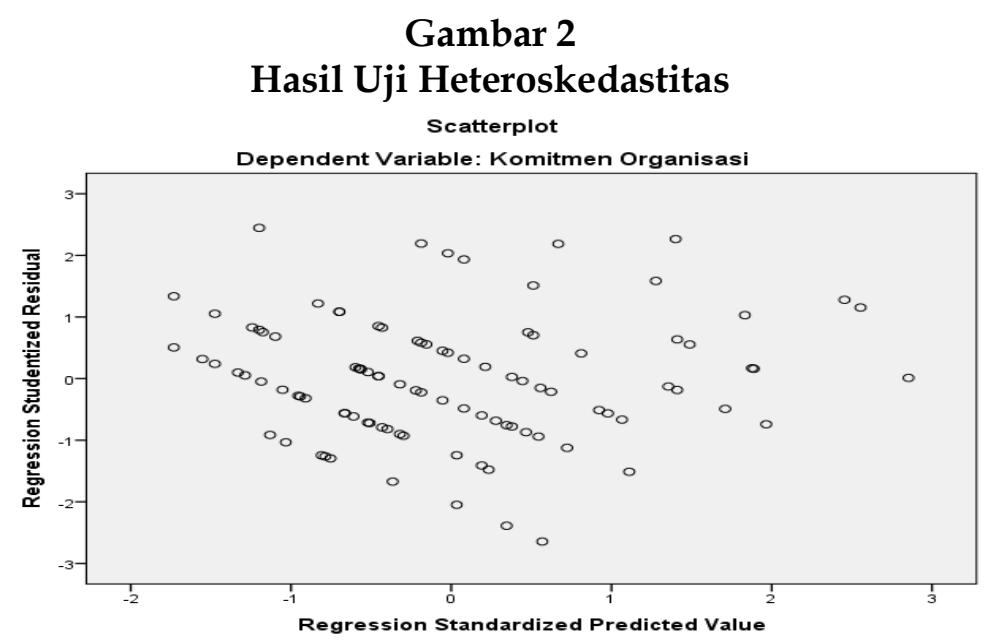

Uji Normalitas

Uji normalitas (Ghozali, 2009:147) bertujuan untuk menguji apakah dalam model regresi kedua variabel dependen maupun independen mempunyai distribusi normal atau tidak. 
Gambar 3

Hasil Uji Normalitas

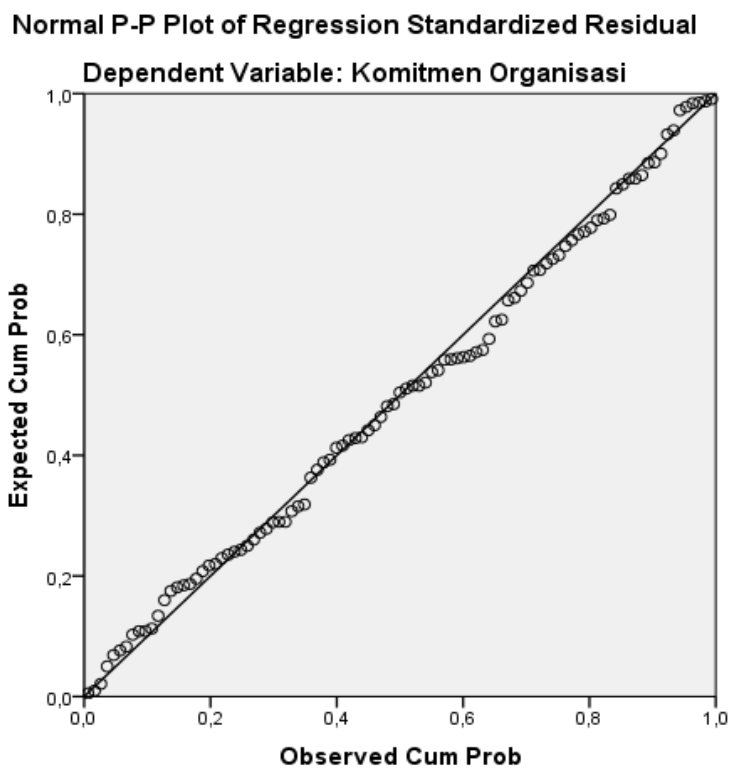

Analisis Regresi Linier Berganda

Tabel 7. Output Analisis Regresi Linear Berganda

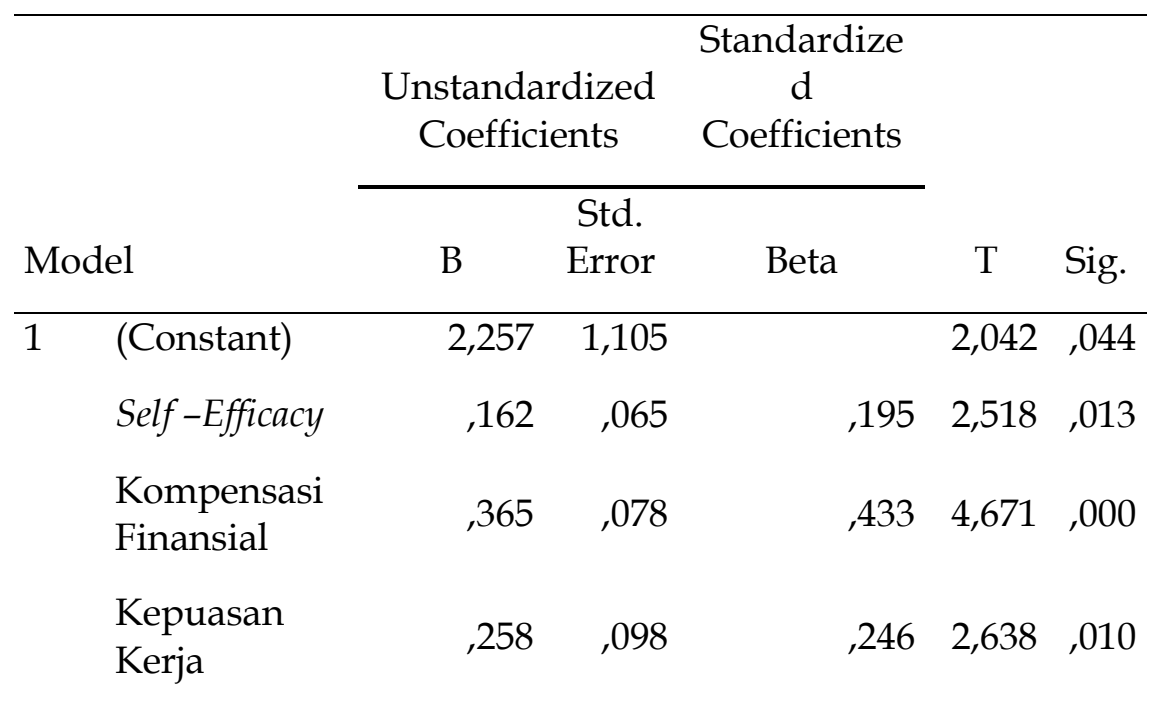

a. Dependent Variable: Komitmen Organisasi 


\section{Uji Hipotesis}

Uji Parsial (Uji t)

Tabel 8. Hasil Uji t (Uji Parsial)

\begin{tabular}{|c|c|c|c|c|c|}
\hline \multirow[b]{3}{*}{ Model } & \multirow{2}{*}{\multicolumn{3}{|c|}{$\begin{array}{c}\text { Standardize } \\
\mathrm{d} \\
\text { Coefficients }\end{array}$}} & \multirow[b]{3}{*}{$\mathrm{T}$} & \multirow[b]{3}{*}{ Sig. } \\
\hline & & & & & \\
\hline & B & $\begin{array}{l}\text { Std. } \\
\text { Error }\end{array}$ & Beta & & \\
\hline 1 (Constant) & 2,257 & 1,105 & & 2,042 & , 044 \\
\hline Self-Efficacy & 162 & 065, & 195, & 2,518 & ,013 \\
\hline $\begin{array}{l}\text { Kompensasi } \\
\text { Finansial }\end{array}$ & ,365 & 078, & ,433 & 4,671 & ,000 \\
\hline $\begin{array}{l}\text { Kepuasan } \\
\text { Kerja }\end{array}$ & 258, & 098, & 246, & 2,638 & ,010 \\
\hline
\end{tabular}

a. Dependent Variable: Komitmen Organisasi

Tabel di atas menunjukan hal berikut:

a. Variabel Self-Efficacy

Persamaan di atas menunjukan bahwa hasil $t_{\text {hitung }}$ sebesar 2,518 $>t_{\text {tabel }} 1,98472$ dengan tingkat signifikansi 0,013 $<0,050$ dan hasil ini berarti variabel self-efficacy berpengaruh positif yang signifikan terhadap komitmen organisasi pada petugas billman di PT. Cita Yasa Perdana Surabaya.

b. Variabel Kompensasi Finansial

Persamaan di atas menunjukan bahwa hasil $t_{\text {hitung }}$ sebesar 4,761 $>t_{\text {tabel }} 1,98472$ dengan tingkat signifikansi 0,000 $<0,050$ dan hasil ini berarti variabel kompensasi finansial berpengaruh positif yang signifikan terhadap komitmen organisasi pada petugas billman di PT. Cita Yasa Perdana Surabaya.

c. Variabel Kepuasan Kerja

Persamaan di atas menunjukan bahwa hasil $t_{\text {hitung }}$ sebesar 2,638 $>t_{\text {tabel }} 1,98472$ dengan tingkat signifikansi 0,010 < 0,050 dan hasil ini berarti variabel kepuasan kerja berpengaruh positif yang signifikan terhadap komitmen organisasi pada petugas billman di PT. Cita Yasa Perdana Surabaya.

\section{Uji Simultan (Uji F)}

Tabel 9. Hasil Uji F(Uji Simultan)

\begin{tabular}{|c|c|c|c|c|c|}
\hline Model & $\begin{array}{l}\text { Sum of } \\
\text { Squares }\end{array}$ & $\mathrm{df}$ & $\begin{array}{l}\text { Mean } \\
\text { Square }\end{array}$ & F & Sig. \\
\hline 1 Regression & 145,831 & 3 & 48,610 & 31,011 & ,000b \\
\hline Residual & 148,916 & 95 & 1,568 & & \\
\hline Total & 294,747 & 98 & & & \\
\hline
\end{tabular}

a. Dependent Variable: Komitmen Organisasi 


\section{b. Predictors: (Constant), Kepuasan Kerja, Self-Efficacy, Kompensasi Finansial}

Berdasarkan hasil uji $\mathrm{F}$ dapat dilihat nilai $\mathrm{F}$ hitung 31,011> nilai $\mathrm{F}$ tabel 2,70, dengan tingkat signifikan $0,000<$ nilai $a=0,05$ sehingga diartikan bahwa variabel self-efficacy, kompensasi finansial dan kepuasan kerja berpengaruh secara bersama-sama terhadap komitmen organiasasi pada petugas billman di PT. Cita Yasa Perdana Surabaya.

\section{Koefesien Determinasi $\left(R^{2}\right)$}

Tabel 10. Hasil Uji Koefesien Determinasi

\begin{tabular}{lcccc}
\hline Model & $\mathrm{R}$ & R Square & $\begin{array}{c}\text { Adjusted R } \\
\text { Square }\end{array}$ & $\begin{array}{l}\text { Std. Error of } \\
\text { the Estimate }\end{array}$ \\
\hline 1 & \multicolumn{1}{c}{, $703^{\mathrm{a}}$} &, 495 &, 479 & 1,252 \\
\hline $\begin{array}{l}\text { a. Predictors: (Constant), Kepuasan Kerja, Self-Efficacy, } \\
\text { Kompensasi Finansial }\end{array}$ \\
b. Dependent Variable: Komitmen Organisasi
\end{tabular}

Berdasarkan Tabel 10 di atas, hasil pengujian menunjukan bahwa nilai Ajusted $\mathrm{R}^{2}$ sebesar 0,495 artinya 49,5\% variabel komitmen organisasi dapat dijelaskan oleh variabel self-efficacy, kompensasi finansial dan kepuasan kerja, sedangkan sisanya sebesar 50,5\% dapat dijelaskan oleh variabel lain yang tidak ada dalam model penelitian ini.

\section{Pembahasan}

\section{Pengaruh Self-Efficacy terhadap Komitmen Organisasi}

Hipotesis pertama diajukan untuk mengetahui pengaruh self-efficacy terhadap komitmen organisasi. Hasil uji t variabel self-efficacy menunjukan bahwa $(2,518)$ lebih besar dari $t_{\text {tabel }}$ $(1,98472)$ dengan tingkat signifikasi $(0,013)$ lebih kecil dari $(\alpha=0.05)$, sehingga hipotesis $(\mathrm{Ha})$ diterima, yang bermakna bahwa self-efficacy berpengaruh positif terhadap komitmen organisasi petugas billman di PT. Cita Yasa Perdana Surabaya. Hal ini berarti semakin baik self-efficacy akan meningkatkan komitmen organisasi. Temuan ini didukung penelitian yang dilakukan oleh Yallo (2018) menunjukan bahwa self-efficacy berpengaruh positif terhadap komitmen organisasi.

\section{Pengaruh Kompensasi Finansial terhadap Komitmen Organisasi}

Hipotesis kedua diajukan untuk mengetahui pengaruh kompensasi finansial terhadap komitmen organisasi. Hasil uji t variabel kompensasi finansial menunjukan bahwa $(4,761)$ lebih besar dari $t_{\text {tabel }}(1,98472)$ dengan tingkat signifikasi $(0,000)$ lebih kecil dari $(\alpha=0.05)$, sehingga hipotesis (Ha) diterima, yang bermakna bahwa kompensasi finansial berpengaruh positif terhadap komitmen organisasi petugas billman di PT. Cita Yasa Perdana Surabaya. Hal ini berarti semakin baik kompensasi finansial akan meningkatkan komitmen organisasi. Temuan ini didukung penelitian yang dilakukan oleh Nurtika (2018) menunjukan bahwa kompensasi finansial berpengaruh positif terhadap komitmen organisasi. 


\section{Pengaruh Kepuasan Kerja terhadap Komitmen Organisasi}

Hipotesis ketiga diajukan untuk mengetahui pengaruh kepuasan kerja terhadap komitmen organisasi. Hasil uji t variabel kepuasan kerja menunjukan bahwa $(2,638)$ lebih besar dari $t_{\text {tabel }}$ $(1,98472)$ dengan tingkat signifikasi $(0,010)$ lebih kecil dari $(\alpha=0.05)$, sehingga hipotesis $(\mathrm{Ha})$ diterima, yang bermakna bahwa kepuasan kerja berpengaruh positif terhadap komitmen organisasi petugas billman di PT. Cita Yasa Perdana Surabaya. Hal ini berarti semakin baik kepuasan kerja akan meningkatkan komitmen organisasi. Temuan ini didukung penelitian yang dilakukan oleh Fitriani (2019) menunjukan bahwa kepuasan kerja berpengaruh positif terhadap komitmen organisasi.

\section{Pengaruh Self-Efficacy, Kompensasi Finansial dan Kepuasan Kerja terhadap Komitmen Organisasi}

Hipotesis keempat diajukan untuk mengetahui pengaruh self-efficacy, kompensasi finansial dan kepuasan kerja secara bersama-sama mempunyai pengaruh yang signitifikan terhadap komitmen organisasi. Hasil uji $\mathrm{F}$ menunjukan bahwa nilai $\mathrm{F}$ hitung $(31,011)$ lebih besar darinilai $F_{\text {tabel }}(2,70)$, dengan tingkat signifikan 0,000 lebih kecil dari $(a=0.05)$, sehingga hipotesis (Ha) diterima yangbermakna bahwa self-efficacy, kompensasi finansial dan kepuasan kerja berpengaruh secara bersama-sama mempunyai pengaruh yang signitifikan terhadap komitmen organisasi pada petugas billman PT. Cita Yasa Perdana Surabaya.

\section{Penutup dan Saran}

Simpulan

1. Self-efficacy berpengaruh terhadap komitmen organisasi. Artinya, semakin baik self-efficacy akan meningkatkan komitmen organisasi, begitpun sebaliknya apabila kurang baik selfefficacy maka semakin rendah komitmen organisasi. Hal ini menunjukan bahwa selfefficacy dapat menstimulasi peningkatan komitmen organisasi pada petugas billman di PT. Cita Yasa Perdana Surabaya.

2. Kompensasi finansial berpengaruh terhadap komitmen organisasi. Semakin baik kompensasi finansial maka akan semakin baik pula komitmen organisasi yang diperoleh oleh petugas billman. Hal ini menunjukan bahwa kompensasi finansial dapat menstimulasi peningkatan komitmen organisasi pada petugas billman di PT. Cita Yasa Perdana Surabaya.

3. Kepuasan kerja berpengaruh terhadap komitmen organisasi. Hal ini menunjukan bahwa kepuasan kerja dapat menstimulasi komitmen organisasi pada petugas billmandi PT. CitaYasa Perdana Surabaya.

4. Hasil uji $\mathrm{F}$ menunjukan bahwa $\mathrm{F}_{\text {hitung }}$ lebih besar dari $\mathrm{F}_{\text {tabel, }}$, dengan tingkat signifikasi lebih kecil dari a. Hal ini menunjukan bahwa variabel self-efficacy, kompensasi finansial dan kepuasan kerja secara bersama-sama berpengaruh signifikan terhadap komitmen organiasasi.

\section{Saran}

1. Diharapkan pihak perusahaan untuk dapat mempertahankan self-efficacy pada petugas billman, karena variabel self-efficacy mempengaruhi komitmen organisasi. Selain itu berdasarkan hasil kuesioner pada variabel self-efficacy didapat nilai rata-rata terendah yang direspon responden yaitu yakin bahwa mampu bertahan menghadapi hambatan dan kesulitan. Sebaiknya atasan PT. Cita Yasa Perdana Surabaya untuk lebih perhatian 
kepada pekerjaan petugas billman saat bekerja di lapangan, apakah mereka menemukan hambatan dan kesulitan. Jika menemukan hambatan dan kesulitan seperti saat melakukan catat meter mereka tidak bisa menemukan solusinya atasan dapat memberikan arahan, supaya jika petugas billman menemukan kejadian yang sulit bisa menemukan jalan keluarnya. Tidak hanya itu saja, atasan di PT. Cita Yasa Perdana Surabaya sebaiknya lebih perhatian kepada pekerjaan billman karena untuk dilihat secara teori pekerjaan billman mudah tetapi diharapkan kepada atasan PT. Cita Yasa Perdana Surabaya untuk bisa merasakan dan memposisikan diri sebagai petugas billman supaya bisa mencapai tujuan yang diharapkan

2. Diharapkan pihak perusahaan dapat mempertahankan kompensasi finansial, karena variabel kompensasi finansial mempengaruhi komitmen organisasi. Berdasarkan hasil kuesioner pada variabel kompensasi finansial didapat nilai rata-rata terendah yang direspon responden yaitu reward. Sebaiknya jika petugas billman sudah berusaha dengan susah payah dan mencapai target yang dibebankan kepadanya untuk pemberian reward lebih di perhatikan, karena sangat disayangkan jika petugas billman sudah mencapai apa yang di harapkan perusahaan, perusahaan tidak memberikan yang diinginkan billman. Untuk kedepannya di harapkan lebih diperhatikan dalam ketepatan waktunya dalam pemberian reward yang berupa uang supaya mereka juga merasa pekerjaan yang mereka kerjakan di hargai oleh perusahaan dan akan menjadikan semangat dan motivasi sendiri bagi petugas billman nantinya. Karena sesuai dengan jawaban responden yang lebih dominan berpengaruh terhadap komitmen orgnaisasi yaitu kompensasi finansialnya.

3. Diharapkan pihak perusahaan dapat mempertahankan kepuasan kerja, karena variabel kepuasan kerja mempengaruhi komitmen organisasi. Berdasarkan hasil kuesioner pada variabel kepuasan kerja didapat nilai rata-rata rendah yaitu hubungan dengan rekan kerja, oleh karena itu pihak perusahaan untuk lebih memperhatikan petugas billman dalam hal hubungan dengan rekan kerjanya. Sebaiknya kepada pihak perusahaan untuk menerapkan kerja dengan sikap kekeluargaan baik hubungan atasan dengan bawahan atau sesama bawahan, supaya nantinya jika ada salah satu dari mereka merasakan kesulitan bisa saling membantu supaya dapat mempermudah pekerjaan. Walaupun disini sudah baik seperti, jika petugas billman mengalami kesulitan akan di bantu oleh koordinatornya, tetapi akan lebih baiknya jika sesama petugas billman dapat saling membantu rekan kerjanya supaya lebih efesien.

\section{Referenasi}

Bandura, A. (2006). Guide for constructing self-efficacy scales. Self-efficacy beliefs of adolescents, 5(1), 307-337.

Buchanan, B. (1974). Building organizational commitment: The socialization of managers in work organizations. Administrative science quarterly, 533-546.

Fitriani, Desy. (2019). Pengaruh Pusat Kendali Internal dan Eksternal, Efikasi Diri dan Kepuasan Kerja Terhadap Komitmen Keorganisasian Karyawan Pada PT. Pasifik Teknologi Indonesia. Business Management Journal, 15(1), 1-67.

Garcia, G. F. (2015). The Relationship Between Self-Efficacy and Employee Commitment Among Perfusionists. Walden University

Ghozali, I. (2009). Aplikasi Analisis Multivariate Dengan Program IBM SPSS, Edisi Keempat. Semarang: Badan Penerbit Universitas Diponegoro 
Gillies, D. A. (1994). Nursing Management a System Approach Third Edition. Philadelphia. Wbsaunders

Handoko, T. H. (2014). Manajemen Personalia dan Sumber Daya Manusia. Yogyakarta: BPFE

Luthans, F. (2002). Organizational Behavior (Tenth Edition). New York: Mc Graw/ Irwin Inch

Luthans, F. 2006. Perilaku Organisasi. Edisi 10. Yogyakarta: Andi

Manara. M. U. (2008). Pengaruh Self-Efficacy terhadap Resiliensi pada Mahasiswa Fakultas Psikologi Universitas Islam Negeri Maulana Malik Ibrahim Malang. Skirpsi. Universitas Islam Negeri Maulana Malik Ibrahim Malang

Marwan, M., Rajak, A., \& Yallo, A. M. (2019). Pengaruh Locus of Control dan Self-Efficacy Terhadap Komitmen Organisasi Pegawai pada Balai Latihan Kerja (Blk) Di Kota Ternate. Jurnal Manajemen Sinergi, 6(1).

Nurtika, H., \& Sariyathi, N. K. Pengaruh Kompensasi Finansial dan Kepuasan Kerja terhadap Komitmen Organisasi pada PT. Asuransi Sinarmas Cabang Denpasar. E-Jurnal Manajemen Universitas Udayana, 7(5), 2764-2792.

Robbins, S. P., \& Judge, T. A. (2003). Perilaku Organisasi. Jilid 2. PT Indeks Kelompok Gramedia, Jakarta

Robbins, S. P., \& Judge, T. A. (2008).Perilaku Organisasi (Organizational Behavior), Terjemahan: Diana Angelica, Ria Cahyani dan Abdul Rosyid. Buku 2. Edisi 12. Jakarta: Salemba Empat

Robbins, S. P., \& Judge, T. A. (2009). Organizational Behavior. 13 Three Edition, USA: Person International Edition, Prentice-Hall

Samsudin, S. (2016). Manejemen Sumber Daya Manusia. Bandung: Pustaka Setia

Simamora, H. 2006. Manajemen Sumber Daya Manusia, Edisi Ketiga, Cetakan Kedua,Yogyakarta: Penerbitan STIE YKPN 